\title{
Dana Bizuleanu
}

\section{Svetlona Alexievich and Posthuman Norratives}

\begin{abstract}
This article sets out to explore tensions and symptoms arising in humanist thought, how they influenced fiction and what is understood as fiction in a decisive manner. In the posthuman paradigm story-telling reveals the inner fractures of humanism and its representations. In recent years, celebrated and awarded writers have introduced hybrid forms of the novel, like in the case of Herta Müller and Svetlana Alexievich. Their books make room for the plural and nomadic subject to explore and recreate an already incoherent life, reality and even death. The narrative voices transgress time and space, in order to showcase how the current (post)human subject, released from any type of framing, looks for proper means of expression.
\end{abstract}

Keywords: Svetlana Alexievich; Hybrid Forms of the Novel; Posthumanism; Female Combatants.

\section{Dana Bizuleanu}

Babeș-Bolyai University, Cluj-Napoca, Romania dana.bizuleanu@ubbcluj.ro

DOI: 10.24193/cechinox.2018.34.21

\section{Humanizing $A I^{1}$ and the Minimal Requirements for Being Human}

1 he first advanced robot is a female robot called Sophia. Advanced, in this case, refers to her outstanding capacity in interacting with humans. Another female robot, Erica, who is 23, can engage in minute-long conversations with people. The companies that have created both Erica and Sophia rely on context-based recreation of emotions and of facial expressions needed for interaction. Considering the technology (a program that uses cognitive psychology to simulate human behavior) developed in the 70s by Herbert A. Simon, two questions arise: Why are these advanced robots (very close to what we imagine under AI) female? And what are the minimum requirements for being human? The latter is subject to a very interesting article in the New York Times, in the paid post section, where the most important researchers and developers of AI discuss how human-like interfaces and the development of feelings in robots seem to open up the possibility for the emergence of independent thinking. Is this a minimum requirement for being human? Or might it be the only requirement? Starting from 
what we do not understand about humans, developers of AI depend on the input of psychologists and philosophers for a better human-robot experience.

The first question on why the designed robots are female can also be subject to scrutiny. As Rosi Braidotti quotes from Simone de Beauvoir: "one is not born, one becomes a woman." From Sophia (Greek and meaning "wisdom"), who wants a family (as she stated on a trip to the Arab world), to Erica, we see how their brains, connected to a $\mathrm{Wi}-\mathrm{Fi}$, express human desires. The female body, in this case, is at the crossing point between cultural designation and biological determination. But is the robot a replica for a human?

The AI saga, but also our bionic future, have put to unrest some humanist principles that have influenced Western thought for centuries. Neither does the Vitruvian Man have bionic arms or legs, nor does he show the possibility that one day humans could perform a head transplant. Moreover, the fragilization of, we could say, the minimal requirements of what it means to be human has led to a refocus on what it means not to be human. In other words, once we remove "the unique, self-regulating and intrinsically moral powers of human reason," ${ }^{3}$ the subject shifts onto what philosophers of the twentieth century have called the margin. Questions regarding center and periphery matter more than never, but embracing binary discourse would be a first. This is the moment in which posthumanism has become an investigative tool for social sciences. Rosi Braidotti argues that the

Eurocentric paradigm implies the dialectics of self and other, and the binary logic of identity and otherness as respectively the motor for and the cultural logic of universal Humanism. Central to this universalistic posture and its binary logic is the notion of "difference" as pejoration. Subjectivity is equated with consciousness, universal rationality, and self regulating ethical behaviour, whereas Otherness is defined as its negative and specular counterpart. In so far as difference spells inferiority, it acquires both essentialist and lethal connotations for people who get branded as "others". These are the sexualized, racialized, and naturalized others, who are reduced to the less than human status of disposable bodies. We are all humans, but some of us are just more mortal than others. ${ }^{4}$

Posthumanism takes the leap into the possibility that the representations "of the non-human, the inhuman, the antihuman, the inhumane and the posthuman proliferate and overlap in our globalized, technologically mediated societies." ${ }^{5}$ What Braidotti points to is not only a decentering of man, but it also reveals how parasitic binary thought, concepts of Otherness and margins can turn out to be. The fragilization of the minimal requirements for being human leads Cary Wolfe to state that posthumanism could signal a moment in history in which man, technology, media and cyber-space merge. ${ }^{6}$ Moreover, for Wolfe,

[1]ong before the historical onset of cyborg technologies that now so obviously inject the post- into the posthuman in ways that fascinate the transhumanists, functional differentiation 
itself determines the posthumanist form of meaning, reason, and communication by untethering it from its moorings in the individual, subjectivity, and consciousness. Meaning now becomes a specifically modern form of self-referential recursivity that is used by both psychic systems (consciousness) and social systems (communication) to handle overwhelming environmental complexity. ${ }^{7}$

Of particular interest would be the idea of how humans instrumentalize meaning for a better grasp of new-found realities. The self-referential recursivity Wolfe claims for meaning comes very close to what Pierre Bourdieu has noted:

Texts circulate without their context, that - to use my terms - they don't bring with them the field of production of which they are a product, and the fact that the recipients, who are themselves in a different field of production, re-interpret the texts in accordance with the structure of the field of reception, are facts that generate some formidable misunderstandings and that can have good or bad consequences. $^{8}$

Without attempting to define what posthumanism is, it would seem more productive and even more practical to engage with its manifestations and symptoms. In the field of language teaching and learning, theories on what multilingualism is have changed (in Europe, at least) the way in which textbooks and strategies for learning foreign languages work. Nowadays humans are not monolingual. The motor for multilingualism is migration, while at the heart of monolingualism are politics, and if we were to look at migration around the world and across the centuries, one would probably find solid evidence for individual, territorial, social and institutional multilingualism. One is considered multilingual when he or she navigates through several languages and can communicate effortlessly in those languages. Moreover, multilingual practices have changed the way we write, speak and think. In an attempt to explain such manifestations, one cannot use the classical framework of exploring and comparing language systems, either in their resemblance, or in their differences. The assault on the concept of mother tongue has already begun and the postmonolingual condition, ${ }^{9}$ as YaseminYildiz defines it, claims that the co-existence between monolingual paradigms and the actual emergence of multilingual practices produce postmonolingual tensions. These become evident in the works of authors like Franz Kafka and Herta Müller. Kafka's works are fueled by his German and encounters with Yiddish and in the case of Müller, language particularities have showcased how graphic and creative German-Romanian words turn out to be.

The prefix "post" in the examples I have described signals therefore tensions inside the self-referential recursivity of meaning. The crisis in which social sciences find themselves forces them to deal with the actual crisis of the human in the posthuman age. In this article I argue that tensions and symptoms arising in humanist thought have influenced fiction and what is understood as fiction in a decisive manner. In the posthuman paradigm story-telling reveals the inner fractures of 
humanism and exposes the impossibility of "unitary identities indexed on that Eurocentric and normative humanist ideal of 'Man'." ${ }^{10}$ Moreover,

Feminist anti-Humanism, also known as postmodernist feminism [...] went further, however, and argued that it is impossible to speak in one unified voice about women, natives and other marginal subjects. The emphasis falls instead on issues of diversity and differences among them and on the internal fractures of each category. In this respect, antihumanism rejects the dialectical scheme of thought, where difference or otherness played a constitutive role, marking off the sexualized other (woman), the racialized other (the native) and the naturalized other (animals, the environment or earth). ${ }^{11}$

In recent years, celebrated writers have introduced hybrid forms of the novel, like in the case of Herta Müller and Svetlana Alexievich. Moreover, the Swedish Academy has awarded the Nobel Prize for literature to writers who explore rather non-traditional forms of fiction, not to mention that Müller and Alexievich are women and Eastern Europeans. Next to Müller's poetic writings and Bob Dylan's music and poetry, we find Svetlana Alexievich's collected and private testimonies of witnesses to the greatest disasters of mankind. Therefore, in one sentence, "[e]verything can become literature," as Alexievich states in the first pages of her book The Unwomanly Face of War.

Herta Müller's writings and essays explore the dystopian reality of Communist
Romania and capture vivid and current manifestations of totalitarianism. Moreover, Herta Müller's usage of a highly poetic language captures the dwellings zones of an incapacitated self. In her novels both language and space dissolve under the pressure of testimony and trauma. ${ }^{12} \mathrm{Nov}^{-}$ els like The Hunger Angel, The Land of the Green Plums or The Appointment revolve around objects and images that dismantle the possibility of a realistic narrative text in which settings and characters take up flesh and a sequentiality of unfolding events. Müller's works augment and expose the inner clockwork of an internal and personal dystopia, in which the reality of totalitarianism and the terror of the secret police escape a clear description. The effort to reconnect to past (traumatic) events leads, for example, the protagonist from The $A p$ pointment to deform and expose a contaminated perception of the body:

The bathroom light threw a face into the mirror as fast as a hand-full of flour flying on a window. Then came a picture with frog-wrinkles where the eyes are and it was me. Water came out warm onto my hands and my face was cold. It is nothing new while brushing my teeth that the paste foams through my eyes. I feel the nausea, spit and stop. $^{13}$

The world of objects and obsessive images (melons, strings, stockings etc.) unfold through an unfiltered perception and find a proper language to express what usually escapes the act of remembering and rendering into words.

Next to how language is embroiled in depicting a fragmented world of details, 
objects, symbols and trauma in Herta Müller's works, we find Svetlana Alexievich's collected testimonies. Alexievich's novels explore the physical experience of war (Zinky Boys, The Unwomanly Face of War) and the disappearance of one's world (Second Hand Times). If Herta Müller's stories already capture a fragmented reality in total discordance with our sense of selves and the world, Alexievich gives voice to individual narrators evoking provisional representations of the self:

The self is a convenient way to hold persons of whatever sort accountable for their actions. Nevertheless, if posthumanism prevails, humanism will be forced to abandon its toehold in the transcendental, and to regard all self-representations as merely provisional: as sometimes useful but always less than necessary fictions, which become burdensome in certain contexts (during discussions of the body or of the minds of animals, for instance). ${ }^{14}$

To some extent, the collection of interviews confronts the fragmented history of disasters and wars, in order to draw a map of emotions. Alexievich's collection of witness accounts of the Soviet-Afghan War, the Chernobyl explosion and World War II and their consequences, reverse, reshape and reconnect the margin, even the erased or ignored figures from manipulated statistics, to a central narration about conflict. In a posthuman key-note, we find Alexievich's collections of testimonies destabilizing mainstream discourse that usually evokes victorious nations and crimes against humanity, but excludes concomitant voices (from both sides, winners or losers) and individual categories (for e.g. women and children). Like in the case of Herta Müller, Alexievich's writings challenge the reader to experience a disparate reality. Moreover, the intensive practice of depicting and narrating details of traumatic events tests the death experience and the borders of the self. In other words,

By transposing us beyond the confines of bound identities, art becomes necessarily inhuman in the sense of nonhuman in that it connects to the animal, the vegetable, earthy and planetary forces that surround us. Art is also, moreover, cosmic in its resonance and hence posthuman by structure, as it carries us to the limits of what our embodied selves can do or endure. In so far as art stretches the boundaries of representation to the utmost, it reaches the limits of life itself and thus confronts the horizon of death. ${ }^{15}$

Even if Braidotti discusses art in general, narrating on liminal experiences evolves into narrations of bodily extinctions. In a posthuman stanza, our own demise is inextricably linked to the disappearance of other species on the planet, be it through total war or natural disasters. ${ }^{16}$

Alexievich's documentary novels or non-fiction narratives reflect particular voices who very often contradict the authenticated, official version of a central history of events. Moreover, initial stories and testimonies narrated by individuals in the books were denied, attacked and even dismissed as lies in the aftermath of publication. Deeply imbedded in society, the experience of conflict belongs to men and the central narration of wartime or even 
disasters has no place for any details, other than facts, names, figures and heroism. As the collection of testimonies unfolds, the bodily experience of conflict introduces the plurality of the subject, in Braidotti's terms. The interviews and the personal narrations of female combatants, war children, and Chernobyl survivors decenter history (of war, of facts and the official narration) and become examples for necro-politics. Following Achille Mbembe's arguments on modern warfare, Braidotti points to the existence of a plural and gendered view on conflict and disaster that implies the segregation of civilian population into rogues, insurgents, refugees and elements to be confined (into camps or designated spaces). ${ }^{17}$ Like in the real world, Alexievich's narrators are severed from the delivered history of events. Therefore truth becomes personal and deeply engraved in the physical experience of violence. The hybrid forms of the novels, written by both Svetlana Alexievich and Herta Müller, are necessary for bridging a gap between a particular experience of violence and a collective one. If Müller opts for the usage of images with a highly-poetic imprint, Alexievich will claim the journalistic genre, in order to merge it with literature for a broader social and cultural impact. ${ }^{18}$ Following Vasily Grossman's and Anna Politkovskaya's conflict chronicles and journalistic endeavors, Alexievich is the writer/journalist laying down the foundation for a debate ${ }^{19}$ between a central/national narration of conflict/disaster and the personal narration. Moreover, even personal narrations found in the book collude, after their publication, with a personal truth. Jeffrey W. Jones describes a trial against the author after the publication of Zinky Boys, during which two grieving mothers claim their accounts where distorted and that Alexievich drew her own conclusions on who their sons were and what they did during the Soviet-Afghan war. ${ }^{20}$ The contradictions in personal narrations arise from a mediated understanding of how soldiers in combat must die. The image of the fallen soldiers implies no human traits, no liability or questionable morals, but sacrifice for a/the motherland.

\section{Writing Prose About the Nightmares of the Twentieth Century}

66】 riting prose about the nightmares of the twentieth century was sacrilege. Nothing may be invented. You must give the truth as it is. A 'super-literature' is required. The witness must speak. Nietzsche's words come to mind no artist can live up to reality. He can't lift it." ${ }^{21}$ Central to Alexievich's documentary novels is the bodily experience of war and environmental disasters. There are also images overriding the bodily experience of war, especially in the case of the female voices present in the books. Soviet women, especially in or during combat and war, are subjected to clear interpretation of status, role and function. There are three main constructs, as Jeffrey W. Jones points out, of the Soviet woman in conflict: motherland-mother, grieving mother and morally-loose woman-at-war. Jones discusses Alexievich's book Zinky Boys and exposes how the three mentioned constructs interact, both in the collected testimonies of survivors and in the public eye. The motherland-mother overlaps with the narrative of the Great Patriotic war, fuelled by the justification for killing and defending. But 
the Soviet-Afghan was war "and yet not war, and, in any case, something remote, without bodies or prisoners [...] Officially we have the same status as the World War II vets. The only difference is, they were defenders of the Fatherland, whereas we're seen as the Germans - one young lad actually said that to me!"22

The inverted narration of the Great Patriotic war, in the eyes of the private telling his story, expresses the liability of central and determinant social structures. Images of war play out in a fragmentary and framed manner, as most of the soldiers' and non-military personnel recall not necessarily victorious battles, but body parts as casualties and sealed zinc coffins for the dead. The construct of the grieving mother, in Zinky Boys, is the antipode of the motherland-mother image. The inconsolable voices in the book ponder at the reason for their sons' deaths, but also question their own narrations (during several lawsuits against Alexievich). There is no need for the truth, as the truth is not complete, in so far as it belongs to the outcasts, the others, the unnamed and the dead for no reason. Sealed in the zinc coffins, truth comes in bodily fragments.

The last construct, morally-loose woman-at-war, revolves around "alleged sexual activity, regardless of [women's] actions" during war $^{23}$ and places the female body at the intersection of what Braidotti has called pan-humanity: an intricate web of relations that does not breed peace and tolerance, but "on the contrary, forms of xenophobic rejection of otherness and increasing armed violence." ${ }^{4}$ The female body plays out these images of violence, through rendering the human in all that is inhumane:
Horses and people fell under the ice. It all happened at night. She grabbed someone she thought was injured and began to drag him toward the shore. "I pulled him, he was wet and naked, I thought his clothes had been torn off," she told me. Once on shore, she discovered that she had been dragging an enormous wounded sturgeon. And she let loose a terrible string of obscenities: people are suffering, but animals, birds, fish - what did they do ${ }^{25}$

Next to female voices depicting war and conflict, there are narrations of a utopia and how a vast space became the ground of an experiment. Svetlana Alexievich captures in Second Hand Times and Voices from Chernobyl the human subject in extinction. Natural disasters and socio-political shifts turn the human subject into a biological species under threat and showcase a fragmented self still very much attached to shared experiences of a country that had stopped existing overnight (in this case the former USRR). The Vitruvian man at the center of humanist thought fails in his moral and political ideals and contemplates his nothingness.

\section{Transfer-Images: Menstruation, Blood, Rape}

$\mathrm{I}$ n my studies on Herta Müller I attempted to explore her nomadic background and the manner in which her texts interact with historical and political tensions (Romanian communism). I therefore turned to the traces of trauma and discussed how elements of trauma infuse the narration and deploy subtle and complex images. The narrative voice in Müller's 
novels dismantles and reframes traumatic experiences, mostly through the usage of a highly poetic language. I called these images transfer-images and defined them as narrative vehicles that contain and retain, metaphorically, the characters' mental and physical relocation. Transfer-images transport the traumatic dimension of such an experience, by configuring the latter spatially and temporally. Transfer-images can signal, on a textual level, other traumas, as they are mechanisms that coagulate and display traumatic experiences.

Such transfer-images are similarly experienced and narrated by female combatants in World War II, as they survive and live to tell of horrors, they are silenced, either by the brutal and paranoiac regime putting on stage a victorious narrative of war, or by their own experience and incapacity to share it. In other words, the telling of how the (female) body experiences violence needs a distinct frame and image to become visible, it involves violence to be and be done at the same time. ${ }^{26}$ The $U_{n-}$ womanly Face of War takes on the task of proving that violence is not exceptionalism and that labeling some acts as war crimes will enable "all other conducts a façade of legitimacy and humanism." ${ }^{27}$ Helen Dexter's brilliant argument also points to the fact that violence "is beyond the control of those who carry it out [...] those who experience violence, witness it or are simply aware of it may infer meaning from the act, the circumstances of violence mean that the original motive (if there was indeed a single coherent motive) is lost." 28 The bodily experience of war plays out in the accounts of rape or the imminence of rape. In the first pages, a male voice talks about Soviet soldiers and how, after years of combat, human sexual behavior turns into violence and rape:

Ten men violated one girl... There weren't enough women, the population fled before the Soviet army, we found very young ones. Twelve or thirteen years old...If she cried, we'd beat her, stuff something into her mouth. It was painful for her, but funny for us. Now I don't understand how I could... A boy from a cultivated family... But I did it... ${ }^{29}$

The actual depiction of sexual predator behavior is censored by the voice's shame if confronted by the nurses accompanying the battalion. Throughout the book, imminence of rape and physical traces of such acts inflict a corporal experience on the narration. Confronted with the proximity of the utter most carnal experience of the other, female voices narrating of rape either ask the interviewer to turn off the recorder, or, distressed, evoke their own role in such crimes. Images of rapes and their casualties are remembered and narrated along with the voice's own incapacity to grasp conflicting feelings about the provisional self she constantly experiences:

I remember... Of course, I remember a German woman who had been raped. She was lying naked, with a grenade stuck between her legs... Now I feel ashamed, but then I didn't. Five German girls came to our battalion... To our commander. They were weeping... The gynecologist examined them: they had wounds. Jagged wounds. Their underwear was all bloody... They had been raped all night long. 
The soldiers stood in line... Don't record this... Switch off the tape recorder... It's true! It's all true!... We formed up our battalion... We told those German girls: go and look, and if you recognize someone, we'll shoot him on the spot. We won't consider his rank. We're ashamed! But they sat there and wept. They didn't want to... They didn't want more blood. So they said... Then each one got a loaf of bread ... You think it was easy to forgive? To see intact... white... houses with tiled roofs. With roses... I myself wanted to hurt them... Of course... I wanted to see their tears... It was impossible to become good all at once. Fair and kind. As good as you are now. To pity them. That would take me dozens of years... ${ }^{30}$

Next to the (violent) invasion of the female body, in both The Unwomanly Face of War and The Last Witnesses (an English translation will be available 2018), female voices evoke either the coming of age (first menstruation) or the complete absence of menstruation during the long war years. Unable to name it but "that woman thing," Albina Alexandrovna Gantimurova sergeant major and scout describes how the crossing into womanhood also meant a suspension of time and place:

"Where are you wounded?" "I don't know where... But there's blood..." He told me all about it, like a father... After the war I went scouting for some fifteen years. Every night. And dreamed things like that my submachine gun refused to shoot, or we were surrounded... I'd wake up grinding my teeth. Trying to remember - where are you? There or here? ${ }^{31}$

The absence of menstruation, as a bodily reaction to combat stress and shell shock, is a sign of a dead organism, as one voice recalls. But it also means that the reorganization of the female body enables a participation in the business of killing. ${ }^{32}$ As controversial as that is in current times, Alexievich's narrators experienced war as an embedded and embodied subject, revealing the material and physical outcome of war. The women in Alexievich's books are the plural, nomadic subject, in which any life/death dichotomies cease to exist. The dead, in absence of menstruation, organism stares at death and turns this "unrepresentable, the unthinkable, and the unproductive black hole that we all fear" ${ }^{\prime 3}$ into a creative and perpetual becoming: ${ }^{34}$

The body reorganized itself so much during the war that we weren't women... We didn't have those women's things... Periods... You know... And after the war not all of us could have children. We all smoked. I also smoked [...] We wore leather jackets, trousers, army shirts, plus a fur jacket in winter. Like it or not something masculine appeared in your gait and your movements. When the war was over, they made us khaki-colored dresses. We suddenly felt we were young girls... ${ }^{35}$

The plural subject in Alexievich's books experiences similar or even identical images of conflict and disaster. The narrators relive in both The Unwomanly Face of War and The Last Witnesses the colors, smells and sounds of war. The corporal 
experience of conflict blurs not only a socalled life/death line, but it also blocks out grander and noble feelings, especially love. The effort to reconnect to such a material experience pushes the subject to see life: "as potentia, energy, even in and through the suppression of the specific slice of life that 'I' inhabit is a way of pushing both post-humanism and postanthropocentrism to the point of implosion." ${ }^{36}$ As the female combatants expose the sounds, smells and colors of war, most of them turn to red/blood as a familiar element and easy recognizable element of war. Memory, in this case, has the vitalist and multidirectional trait of taking the chance to "mix and match, mingle and multiply the possibilities of expansion and relations among different units or entities." ${ }^{37}$

I also think this... Listen... How long was the war? Four years. Very long... I don't remember any birds or flowers. They were there, of course, but I don't remember them. Yes, yes... Strange, isn't it? Can they make a color film about war? Everything was black. Only the blood was another color, the blood was red... ${ }^{38}$

Other accounts in the book reveal the heavy black color of blood or how it thickens on one's clothing, flows, mixes with lice or filth. In the snippets of interviews where the color red and its facets appear, the narrating voices turn to a concrete material description of it. In other words, the skinlike experience of blood/red shows how memory, fragmented and dispersed memory can select and produce imagination. The transformative power of central, shared and similar images of events (transfer-images) release themselves from a central, historical narrative of events: "The mechanism of human memory is selective, transformative, and thus productive of historical imagination, whereas the general inventory of photography in accordance with media logic registers temporal events without demanding a binding historical narrative." ${ }^{39}$

And now we return to Sophia and Erica, two female robots and their outstanding skills for interacting with humans. These two robots stand out, as a lot of their kin is used in military operations, operating rooms or in nuclear plants. They possess an outstanding number of facial expressions, but not a broad area of emotion models. As scientists try to simulate human feelings and make Sophia become wise, the bodily experience of emotions lags behind. Sophia and Erica need not merely to interact and react on the basis of a model of feelings, but a complex network of wires, cables and circuits (imitating our complex bio-rhythm) to achieve the corporal manifestations of feelings and emotions. Like in the case of Alexievich's female survivors, the two robots test the minimal requirements for being human: how to find accurate representations of a lived life.

\section{In Lieu of Conclusion}

$\mathrm{P}$ osthumanism has amassed momentum due to an ever-growing complexity of human life. Moreover, this complexity signals a very disparate reality, but also a set of interwoven relations between the human, the non-human, the material, nature, etc. Herta Müller's and Svetlana Alexievich's books make room for the plural and nomadic subject to explore and recreate an already incoherent life, reality and even 
death. The narrative voices transgress time and space, in order to showcase how the current (post)human subject, released from any type of framing, looks for proper means of expression. Through the transformative power of narration and imagination, the nomadic subject has this world engraved in him/her.

\section{Works Cited}

Alexievich, Svetlana, The Unwomanly Face of War. An Oral History of Women in World War II, translated by Richard Pevear and Larissa Volokhonsky, New York, Random House, 2017, Epub

Alexievich, Svetlana, Zinky Boys. Voices from the Afghanistan War, translated by Julia and Robin Whitby, New York, W.W. Norton \& Company, Inc., 1992, Epub

Bourdieu, Pierre, "The Social Conditions of the International Circulation of Ideas," in Richard Shusterman (ed.), Bourdieu. A Critical Reader, Oxford, Blackwell Publishers, 1999

Braidotti, Rosi, The Posthuman, Cambridge, Polity Press, 2013

Dexter, Helen, "Terrorism and Violence: Another Violence is Possible?," Critical Studies on Terrorism, Vol. 5, No. 1, April 2012, pp. 121-137

Eddy Driver, Beverley, "Testimony and Trauma in Herta Müller's Herztier," German Life and Letters, No. 53, vol. 1, 2000, pp. 56-72

Ernst, Wolfgang, Digital Memory and the Archive, Minneapolis, University of Minnesota Press, 2013

Jones, Jeffrey W., "Mothers, Prostitutes, and the Collapse of the USSR: The Representation of Women in Svetlana Aleksievich's Zinky Boys," Canadian Slavonic Papers, Vol. 59, No. 3-4, 2017

Müller, Herta, Heute wär ich mir lieber nicht begegnet, Hamburg, Rowohlt, 1997

Philips, Dana, "Posthumanism, Environmental History, and Narratives of Collapse," Interdisciplinary Studies in Literature and Environment, No. 22.1, 2015, pp. 63-79

Rodgers, James, "From Stalingrad to Grozny: Patriotism, Political Pressure, and Literature in the War Reporting of Vassily Grossman and Anna Politkovskaya," Media, War \& Conflict, No. 7(1), 2014, pp. 23-36 Wolfe, Cary, What is Posthumanism?, Minneapolis, University of Minnesota Press, 2010

Yildiz, Yasemin, Beyond the Mother Tongue: The Postmonolingual Condition, New York, Fordham University Press, 2012

\section{Notes}

1. https://paidpost.nytimes.com/ubs/what-it-takes-to-be-human.html (accessed December 18, 2017).

2. Rosi Braidotti, The Posthuman, Cambridge, Polity Press, 2013, p. 3.

3. Ibidem, p. 13.

4. Ibidem, p. 15.

5. Ibidem, p. 2.

6. Cary Wolfe, What is Posthumanism?, Minneapolis, University of Minnesota Press, 2010, p. 16.

7. Ibidem, p. 20.

8. Pierre Bourdieu, "The Social Conditions of the International Circulation of Ideas," in Richard Shusterman (ed.), Bourdieu. A Critical Reader, Oxford, Blackwell Publishers, 1999, p. 221.

9. See Yasemin Yildiz, Beyond the Mother Tongue: The Postmonolingual Condition, New York, Fordham University Press, 2012.

10. Braidotti, op. cit., p. 27.

11. Ibidem, p. 27.

12. See Beverley Eddy Driver, “Testimony and Trauma in Herta Müller's Herztier," German Life and Letters, No. 53, vol. 1, 2000, pp. 56-72. 
13. Herta Müller, Heute wär ich mir lieber nicht begegnet, Hamburg, Rowohlt, 1997, p. 22, my own translation.

14. Dana Philips, "Posthumanism, Environmental History, and Narratives of Collapse," Interdisciplinary Studies in Literature and Environment, No. 22.1, Winter, 2015, p. 64.

15. Braidotti, op. cit., p. 107.

16. Ibidem, p. 111.

17. Ibidem, p. 123.

18. James Rodgers, "From Stalingrad to Grozny: Patriotism, Political Pressure, and Literature in the War Reporting of Vassily Grossman and Anna Politkovskaya," Media, War E Conflict, Vol. 7(1), 2014, p. 34 .

19. Ibidem, p. 35.

20. Jeffrey W. Jones, "Mothers, Prostitutes, and the Collapse of the USSR: The Representation of Women in Svetlana Aleksievich's Zinky Boys," Canadian Slavonic Papers, Vol. 59, No. 3-4, 2017, p. 10.

21. Svetlana Alexievich, Nobel Lecture, 2015, p. 6, https://www.nobelprize.org/nobel_prizes/literature/ laureates/2015/alexievich-lecture_en.pdf (accessed December 20,2017).

22. Svetlana Alexievich, Zinky Boys. Voices from the Afghanistan War, translated by Julia and Robin Whitby, New York, W.W. Norton \& Company, Inc., 1992, Epub.

23. Jeffrey W. Jones, op. cit., p. 13.

24. Rosi Braidotti, op. cit., p. 40.

25. Svetlana Alexievich, Nobel Lecture, 2015, p. 9, https://www.nobelprize.org/nobel_prizes/literature/ laureates/2015/alexievich-lecture_en.pdf (accessed December 20,2017).

26. Helen Dexter, "Terrorism and Violence: Another Violence is Possible?," Critical Studies on Terrorism, Vol. 5, No. 1, April 2012, p. 134.

27. Ibidem, p. 131.

28. Ibidem, p. 130.

29. Svetlana Alexievich, The Unwomanly Face of War. An Oral History of Women in World War II, translated by Richard Pevear and Larissa Volokhonsky, New York, Random House, 2017, Epub.

30. Ibidem.

31. Ibidem.

32. Braidoti, op. cit., p. 114.

33. Ibidem, p. 131.

34. Ibidem, p. 137.

35. Alexievich, The Unwomanly Face of War. An Oral History of Women in World War II, ed. cit.

36. Braidoti, op. cit., p. 137.

37. Ibidem, p. 157.

38. Alexievich, The Unwomanly Face of War. An Oral History of Women in World War II, ed. cit.

39. Wolfgang Ernst, Digital Memory and the Archive, Minneapolis, University of Minnesota Press, 2013, p. 44. 